Recapturing the Household. Reflections on Labour, Productive Relations and Economic Value

Marit Melhuus

\title{
Introduction
}

The past decades have seen a significant shift in the organization of labour and capital, where emphasis is placed on flexibility and outsourcing of labour tasks. With increasing urbanization and a concomitant expansion of the informal economy, precarious labour is for growing numbers in many parts of the world a grim reality. However, as Millar reminds us: 'In many countries of the global South ... precarious work has arguably always been part of the experience of the labouring poor' (2014:34; Bremen 2013). And as Narotzky (this volume)

reiterates: 'Dislocation is not new in the process of expansion of capitalism nor in past historical forms of predatory conquest.' Anthropologists have increasingly documented these realties from various perspectives (eg Han 2012, Lazar 2008, Goldstein 2003, Cross 2010).

Nevertheless, there is great variety in how labour is configured under contemporary capitalism. With specific reference to the figuration of labour and capital, Tsing argues 'that diversity conditions the responses of both capital and labor to the problem of cutting labor costs and disciplining the workforce' (2009:150). She shows how global supply chain capitalism generates forms of labour that are not only based on self-exploitation but also on what she terms 'super- exploitation' (such as gender, race, ethnicity, and, I would add, kinship 
and religion) (ibid 158), drawing attention to the non-economic factors implied in labour performance. Bringing together the economic and non-economic aspects of labour, Tsing reminds us of an important dimension of any labour configuration: that labour practices are always embedded in specific sociocultural settings.

The last years have also seen an increased focus on affect and affective labour, in particular with regard to neo-liberal transformations. The current emphasis on the non-economic factors of labour reconfigures labour practices in other terms, potentially displacing the questions tied to economic value and the very grounds for capturing labour performed as self-exploitation or even superexploitation. With the continual deregulation of the labour market and the simultaneous drive to cut labour costs, it seems an urgent task to grasp the way such processes inflect on the organization of everyday labouring lives. As Hann and Hart point out (2011: 170) 'Even in a post-Fordist, post-modern age, most people still have to work for a living'.

In their call for a rethinking of the nature of economic life, Narotzky and Besnier (2014) focus more broadly on social reproduction and those complex phenomena that come together in the way ordinary people go about making a living - or a 'life worth living' (2014: S5). They centre on the importance of worth in making a livelihood. The term 'livelihood' embraces more than labour practices, pointing to a moral dimension of economic activity and hence to relations of commitment and also dependency, such as for example kinship. Central to their approach, in addition to crisis and hope, is a consideration of 
value. Although accepting Graeber's reinterpretation of the labour theory of value 'that defines value as the spending of creative energy in producing and maintaining society' (ibid: S6), they are attentive to different co-existing regimes of value, combining political economy with a moral economy (as well as a feminist economics). Their broad stroke is an invitation to bring regimes of labour and regimes of value within the same frame.

In this paper, I suggest that the household represents a viable and fruitful analytic concept not only in explorations of contemporary, precarious labour regimes, but also as a way to bring regimes of labour and co-existing regimes of value within the same frame. Much of the activities that sustain people and livelihoods worldwide are household based. To the extent that household activity is productive, household analysis provides a way to explore not only the way labour is mobilised and deployed to make a life and create a livelihood, but also - and just as important - to grasp the way economic value and sources of profit and accumulation are generated. This would contribute to our knowledge of the working and living conditions of many urban and rural poor across the world, while yielding insights to the continued reproduction of structures of inequality. Household analysis provides an ethnographic access to a particular temporal dynamics that is revealing of a layered texture of precariousness, capturing at one and the same time the material realities and the intimate relations of living, and how these are interlaced.

Household, in my usage, is not reserved for non-market economies. It is not a term solely applicable to pre-industrial societies, as Polanyi would have it. 
This specificity would, as Gregory points out, limit the usefulness of household (Gregory 2009). Nor do I consider the household as confined to autarkic, self sufficient peasant production. Rather, in line with Gregory, I view householding as embedded in market relations, straddling both the market and non-market domain (Gregroy 2009: 144). ${ }^{\mathrm{i}}$ For my purposes, the household is a useful tool for particular ethnographic enquiries, and my specific focus is tied to the nature and character of household labour. However, what place the household has in an economy, will necessarily be an empirical and historically contingent issue (see also Campbell this volume).

My discussion on the household is based on fieldwork carried out in 1974 - 75 among landless tobacco growers in Corrientes, Argentina. In retrieving this work, I wish to draw attention to the potentials of a particular perspective. My engagement with the household and more specifically household analysis was triggered by a specific research interest. That interest centred more broadly on agrarian issues related to social inequality and processes of social transformation. At the time (and especially for those working in Latin America) these questions were framed in terms of the 'peasant debate'. More concretely, my focus was on economic value, the creation of a surplus and its eventual appropriation. This demanded a more detailed examination of labour and labour practices. My assumption was that labour is the source of economic value, thus my perspective was what Gregory terms 'production-centric' (2014:52). And my queries were directed at the ways in which economic value was created and circulated. 
Wolf's now classic piece Peasants was an inspiration, especially his discussion of surplus and 'social surpluses' (1966: 4-10). Wolf contends that peasants necessarily produce a surplus, that this surplus takes different forms and that "the term "peasant" denotes no more than an asymmetrical structural relationship between producers of surplus and controllers; to render it meaningful, we must still ask questions about the different sets of conditions which will maintain this structural relationship' (ibid 10). In this paper, I will not address the peasant or the peasantry as such ${ }^{\mathrm{ii}}$. My point is rather methodological. In order to come to grips with surplus production and the nature of conditions under which it is created and appropriated, I needed an analytical framing that would allow for a detailed and systematic generation of particular data. Household analysis served this purpose well. However, at issue in the present context is whether such analysis may also be productive for contemporary labour issues, which may be far removed from rural concerns.

\section{A time and a place}

In May 1974 I (literally) set sail for Argentina, departing from the Norwegian port of Ålesund.iii After about 5 weeks at sea, on a 'work-a-way' contract, we disembarked in Buenos Aires. Some days later, we arrived in Goya, Corrientes, about 1000 kilometres North East of the capital. Goya was a hub for the producers of black tobacco, the criollo correntino, which was one of the main crops of that area at the time. My research was to focus specifically on the landless tobacco growers and their nascent political mobilisation. My choice of this particular place at this particular time was an interest in agrarian sociopolitical movements and not least processes of rural social transformation. 
I had been spurred by the optimism that prevailed in Argentina in the wake of Hector Campora's presidency in 1973 and the return of Juan Domingo Peron from his exile in Spain and subsequent ascent to again become President of the Republic. Peron's return was an extraordinary event. He encapsulated the drive for change and the hopes for a better future, while at the same time laying the ground for the troubled times that followed. There was a surge of interest for a whole range of social problems with a goal to confront and solve them. The agrarian sectors were given particular attention and the Agrarian Leagues (Ligas Agrarias), organizing peasants and farmers in the northeast provinces of Argentina had won wide support and their demands were in part being met.iv The Ligas Agrarias Correntinas (LAC) were formed in January 1972. In 1973, they had organized a 'strike', i.e. a refusal to deliver and market their harvested tobacco. The 'strike' lasted about a month. Their immediate demands were higher prices, a more just classification system and guarantee of purchase. I was going to work closely with the Ligas Agrarias Correntinas. ${ }^{\mathrm{v}}$

Shortly after my arrival, Peron died (July $1^{\text {st }}$ ). Isabelitavi, his wife and vice-president, took office as president of the nation. She left the reigns to Lopez Rega (already an important confidante of Peron) and the feared 'Triple A' (Alianza Anti-Comunista Argentina) stepped up its operations. Death lists were published; people were killed or disappeared. Terror began to permeate all sectors of the Argentinian society. The political momentum of the Agrarian Leagues of Corrientes was thwarted, their political activity effectively forbidden; their leaders persecuted, jailed and tortured. In the wake of this political 
violence, the Ligas not only lost their nascent bargaining power in their attempt to gather tobacco growers collectively behind particular demands, lost also, and perhaps as important, was a potential sense of community that might have contained further acts of dislocation (see Schober, this volume, on the role of unions in labour struggles). This was the start of a bleak and dark period of Argentina's recent history, the dirty war, la guerra sucia, which only ended in 1983 with Raúl Alfonsin being elected president. The political climate exacerbated the social and economic insecurities of these tobacco producers.

This tense political situation forced me to redesign my research project. The increasing threat of state violence stopped the political mobilization of these rural poor cultivators, while simultaneously frustrating an anthropological endeavour. It was definitely not wise to study political processes; more importantly, it was not feasible. Rather than focus on political processes, I focussed on economic ones. Politics and economy are intimately linked and through a detailed study of the production and marketing of black tobacco, I was also able to get at the underlying conditions that structured this agrarian sector. Indeed, it was precisely the precarious economic situation of the tobacco growers that had spurred their truncated political involvement. The majority of these tobacco growers were landless peasants, producing a crop for one of the major industries in Argentina. Locally, the production of black tobacco was referred to as 'el cultivo de la misería' (the crop of wretchedness), a poignant reminder not only of the labour efforts involved in producing tobacco, but also of their vulnerability, situated as they are between landowners, the tobacco industry and the state - as well as being susceptible to the vagaries of the 
weather. vii I chose to locate my research to an estancia - or large estate - that organized its economic activities around cattle and tobacco production. ${ }^{\text {viii }}$

\section{My framework - then}

My overall research interests were related to what has been coined 'the agrarian question' (McMichael 1997), and as mentioned my specific interests were in processes of social transformation: rural change and the potential role of a peasantry in such processes, especially as these were played out in Latin America. At the time of my study, the distinction between pre-capitalist and capitalist societies was analytically relevant, although challenged. The 'dual economy' thesis and modernization theories had been discarded in favour of dependency theories; structural inequalities were articulated through world systems theories. Politically the term 'imperialism' was applied not only to denote the structural inequalities in the world but also as a rally for struggle and international solidarity. There was an overall concern with development processes and processes of social change more generally, with a particular focus on rural development. It was within such a scenario, that the peasant gained an important place and studies of peasant societies flourished.

Drawing on such scholars as Wolf (1966), Shanin (1971), Meillassoux (1973), Stavenhagen (1973), Mintz (1973), Sahlins (1974) and also Chayanov (1966), I was interested in what I then termed as 'the character of integration' of what could be coined as a 'peasant economy' to society at large. Working from the premise that the basis for this particular social formation (i.e. the tobacco 
production in Corrientes) was one of social and economic inequality, I was interested in what restricted - or generated - a process of accumulation amongst the tobacco growers, potentially allowing for a reinvestment in a more expansive production. To this end the notion of surplus - or more precisely economic surplus - was central. My question was not whether a surplus was produced but rather how (or by whom) that surplus was appropriated. The problem (as I phrased it then) was not 'that peasants are unable to produce a surplus, but [rather] that they are unable to realise it'.

My framework was Marxist. ${ }^{\text {ix }}$ My arguments were framed in terms of relations of production, labour, and unequal exchange. Although accepting that the dominating 'mode of production' was capitalist, I argued that this did not necessarily entail that a capitalist logic informed all forms of economic activity. Thus, my focus was on forms of labour and the way different labour regimes are subsumed under a more overarching capitalist rationality. These landless tobacco cultivators were commodity producers. Yet, they were not wage earners; they were not employed (neither were they in Denning's term 'wageless', Denning 2010). In other words they were not what would (then) be classified as rural proletarians. Rather we could say that they were 'self employed'. In a limited sense, their production efforts could be viewed as an example of unpaid labour. However, none of these terms fully captures their way of life and their various dependencies. With the exception of land, they did control their means of production. But most importantly they controlled their own labour. The tobacco cultivators were producers of an industrial commodity - tobacco - supplying the raw material to an industry that dominated a 
significant global market, namely that of cigarettes. Hence, they were totally dependent on a market in order to realise the value of their productive efforts. Moreover, they were totally dependent on a landowner in order to produce at all. ${ }^{x}$

Access to land was achieved through contracts of apacería (rent in kind) with the landowner. In my case, these apaceros (as they were called) paid $30 \%$ of their harvest to the landowner, an estanciero (estate owner) whose property consisted of 3700 hectares. $^{x i}$ In so far as a tobacco cultivator was attached to a large landowner, a producer could potentially have unlimited access to land, granted the land was suitable for tobacco cultivation, the labour power available and the landowner granted access. Increased tobacco production would serve the interest of both the landowner and the tobacco cultivator: the better the harvest, the better the income, for both. The opposite, obviously, also holds true. Regarding the commercialization of the tobacco, the cigarette industry was in a monopoly position. The buyers of tobacco present in the area set the terms: fixing the price and the quality criteria. Thus the demands of the cigarette industry - both in quality and quantity - and the price it was willing to pay directly affected the incomes of both the tobacco producer and the landowner.

\section{Configuring labour: household analysis}

The labour regime that I studied is the product of a particular historical conjuncture. This history is expressed through specific relations, such as the property structure, the land tenure system and the development of the tobacco 
industry in Argentina. These relations are in turn embedded in certain practices, tied to the specificities of black tobacco and its cultivation and eventual commercialization. In this labour regime the critical factors are land, technology and labour power. As I have already indicated, the property structure was characterised by a concentration of land on a few hands. Hence, most of the tobacco cultivators were landless.

I turn now to the way I chose to approach my fieldwork, concretely and specifically. What kind of evidence did I need to gather in order to answer the particular questions I had set for myself? How did I configure my focus on surplus? Two points are central. One has to do with the very characteristics of black tobacco. What does cultivating black tobacco entail in terms of land, labour and technology? The other has to do with labour and how this labour was organized. Which units of analysis would work for me? At the time, and with my explicit focus on economy, the household served as my point of entry.

I had been trained in household analysis with a specific focus on household viability. A household, we were taught, is at one and the same time a unit of consumption and a unit of production. Household refers to organized groups that act as decision-making units, regarding production, distribution, and consumption. A household could also be considered a redistributive unit where relations of dependency and mutuality co-exist. A household may be composed of members that are not family or kin. Thus, a household is not necessarily a family, but it may be. Central to household analysis, then, is household composition, and in particular the relationship between consumers and 
producers (non-productive and productive labour). This balance is critical for the household's viability, articulating the relationship between production and reproduction. Moreover, as this relationship shifts over time, focus should be directed at the developmental cycle of the household, in order to capture the critical moments of fusion and/or fission (see Goody 1969, especially the introduction by Fortes, and the chapter by Stenning). Attention was directed at the organization of production/consumption within each household, as well as an examination of the relationships between households. Thus, both intra- and inter-household relations were in focus. The household, then, as a unit of analysis captures a particular temporal and relational dynamics, which sheds light on how resources are effectively managed, over time. In this framework, labour practices are crucial.

A focus on household and household viability opened two paths of exploration. On the one hand, I detailed the actual composition of each household, registering all members and their relations to each other. Among other things, this revealed strategies for extending the reproductive cycle such as 'adopting' or incorporating children (of for example an unwed daughter) into the household or attaching single men (who may or may not be kin) to the household. It also revealed an extensive out migration of household members. By combining a registering of family histories and migratory patterns, I also gained insight into the developmental cycle of each household. On the other hand, by focussing on labour practices, I was able to attend to the entire productive cycle of tobacco, the amount and kinds of labour required at each stage as well as the technology employed. I also paid attention to subsistence production as well as 
other activities that sustained the household over time. A specific focus on viability also made evident the critical points that determined the amount of tobacco each household could produce. While revealing the precarious position of these tobacco cultivators, the analysis also demonstrated incipient processes of social differentiation. ${ }^{x i i}$

Black tobacco is characterized by its labour intensity. This is in contrast to light tobacco (Burley and Virginia). Black tobacco is dark and rough and relatively heavy. Its special flavour results from the drying and curing process which (at the time) was not mechanized and therefore dependent on sunny weather. In fact, at the time of my fieldwork, very few of the labour processes involved in black tobacco cultivation were mechanized. The technology applied was simple. For traction-power mules, horses or oxen were mainly used, though the tractor was gaining ground. All other operations were manual. There were two peak periods in the cycle: one at the time of transplantation of the tobacco plants from the seed-beds to the field, the other at the time of harvest. Whereas it was possible to mobilise extra hands (from other households) during the time of transplantation, this was not possible at the time of harvest. All available hands in each household were needed to harvest, bundle, dry and sort the tobacco in preparation for commercialization. In fact, it was the 'harvesting capacity' of any one household that determined the amount of tobacco that was planted; this was the crucial factor in planning the production cycle.

As mentioned, my interest turned on the notion of economic value, the creation of a surplus and its circulation and appropriation, whether as a source 
of profit or potential accumulation. The challenge was to find a way to make the surplus 'evident'. With regard to the $30 \%$ rent transferred to the landlord, the surplus forfeited was obvious. But what about the price mechanism? Did the price obtained for the tobacco also reflect an unequal exchange, a more covert transfer of economic surplus? If you recall, the price of the tobacco was one of the main issues that the Ligas Agrarias had raised, and which provoked the 'strike' of not delivering their tobacco for sale. (The other was the classification criteria.) Thus, with regard to price there was definitely a felt sense of injustice. Moreover, the mere fact that prices were up for negotiation (as the LAC had proved) indicated that there was a certain leeway that could be exploited. In order to make a probable argument, I needed to do a series of calculations related to production cost and value of labour power. I cannot render these calculations here, but refer to my original work for the details (Melhuus 1987: 180-214). Suffice it to say, that through my calculations I was able to establish that the price of tobacco was such that the majority of the tobacco cultivators were producing under conditions that did not permit accumulation; they did not get their 'labour's worth'. Moreover, I argued that were there was an 'invisible' surplus, expressed through the market-price mechanism, which was transferred to the industry.

The crux of the argument lies in the fact that for these peasants labour did not enter as a cost factor. These cultivators were operating under a different economic rationality (than that of a strictly capitalist enterprise), a different labour regime which not only allows for, but is in a sense based on, a notion of unpaid labour. But the notion of unpaid labour implies more than mere fact that 
they do not calculate labour in terms of cost. It also points to the issue of economic surplus - and the appropriation and realization of this surplus. In so far as there is a relation of unequal exchange - both with regard to the land rent and with regard to the price mechanism, this surplus is siphoned off, to be realized by others, in an 'asymmetrical structural relationship between producers of surplus and controllers' (Wolf 1966:10). My argument then was that the economic rationality that underpinned this production was based on auto-exploitation and it was this factor that made it profitable to maintain this particular peasant economy. And with regard to social change, my point was that any systematic accumulation, that could transform their lives and livelihoods, was very difficult to achieve. The property structure and the land tenure system, as well as the tobacco industry, were conducive to maintaining a status quo.

\section{Vulnerable lives}

My systematic focus on household and household composition, the relation between productive and non-productive labour, and household viability was directed at demonstrating how an economic unit was reproduced and how this very process of reproduction also reproduced relations of a different order. The way I framed my question with regard to surplus, required a particular kind of evidence. However, this close examination of daily lives also revealed an extremely precarious situation.

These peasants were poor; they made their living on the very margins of society. There was good reason to call tobacco the 'crop of misery'. People were 
very conscious of their poverty and explicitly tied their poverty to a specific morality, where being good and being poor were equated. They did not necessarily yearn for wealth, but hoped for a decent life. Their houses were made of mud or reeds, with earthen floors and thatched roofs. A family would have one main construction consisting of one room, partitioned by a cupboard or the like. Here the parents, daughters and younger children slept, sharing beds. The older boys would sleep in a partition of the galpon (a larger shed for storage of equipment, drying tobacco etc). Cooking was done over an open fire, in a separate small construction. There was no piped water, nor electricity. The most usual source of water was the nearest pool of almost stagnant water, where people washed, cows meandered and drinking water was fetched. A few families had constructed a well.

Most of the older people were illiterate, although extremely knowledgeable about tobacco cultivation and agriculture more generally; the women had extensive knowledge of local healing herbs. There were few local institutions. There was no church, only a small chapel that the priest attended nine days a year. There was no health centre in the rural area; for any emergency they had to go to Goya, although transport was hard to procure. In town, these peasants were often the last to be attended, irrespective of having arrived first. The local school was hard to get to, and although education was seen as important, many of the children did not attend regularly. Amongst themselves they would often speak guarani; and they listened to Radio Paraguay (guaraní is the official language in Paraguay, along with Spanish). The men dressed in the traditional bombachos, the black sombrero and riding boots or alpargatas; the 
women wore cotton dresses or pants with T-shirts. At the time of harvest, money might be spent on one new set of clothing, for each family member.

Yanagisako (1979) has pointed out that peasants are exposed to particular risks (eg the market, state, the weather). These tobacco producers are no exception. In fact we can deduce a layered texture of precariousness. In addition to material poverty, they lived with the insecurity and risk entailed in being landless, at the mercy of landowners. They were also subject to the vagaries of the weather in ensuring a good harvest; whether they would be able to sell their crop at a good price. At a larger scale, there was the threat that the tobacco industry might shift its priorities, light tobacco eventually supplanting the criollo correntino. Moreover, the institutional void implied a weak sense of community that could potentially tie these people actively together; there were no organizations that could mobilise them in a mutual cause. In fact the demise of the Ligas Agrarias implied inter alia a cessation in the circulation of information regarding trends in the market, the debt crisis in Argentina and other macro-economic factors that impinged on their everyday lives. Thus their very ignorance of significant contextual factors is a contributing element to their already volatile existence. Hence, many of these peasants were kept in place by both the economic and the political circumstances that framed their lives. Others had no option but to migrate. Those who stayed survived by mobilising all available hands, irrespective of age or gender. Thus, the question of selfexploitation must also be read in light of the internal power relations and dependencies, adding yet another layer to the very workings of the household and its vulnerability. 


\section{Recapturing the household}

At an abstract level, labour regimes are ways to organise the economy. Yet labour regimes are also more: they organise lives. In this sense, any labour regime is concretely and locally manifest. I have argued that household analysis is one way of accessing specific labour regimes. Moreover, I have suggested that a household can be viewed as a site where regimes of labour and regimes of value coalesce, thus bringing economic value and moral values into the same frame. At the core of my analysis of the tobacco growers was a concept of value, explicitly related to labour and economic surplus. Thus I was mainly concerned with economic value. In his extended discussion of value, Graeber states: 'that value is the way actions become meaningful to the actors placed in some larger social whole, real or imaginary' (Graeber 2001: 254). This perspective, which places the power of creativity as its core, locates value to meaning and imagination. Although embracing a significant dimension of value, it is not very helpful in capturing forms of economic value: how these are creatively produced and circulated or even creatively usurped.

With a dual focus on economic surplus and household organization of labour, I was able to show how particular relations of social inequality were generated and reproduced. I was also able to indicate the tensions and contradictions in these relations. Holding these contradictions together were the tobacco-producing units and the way their labour power was configured within this wider socio-political structure. This configuration rested on the very fact 
that labour was unpaid and did not enter as a cost factor. That there are ways of subsuming labour that is more profitable than wage labour is not unique to this particular case. Rather, it is probably the reality for many working poor all over the world. Hence, there is a need to document ethnographically the diverse ways in which labour costs are cut or even effectively erased (for a different perspective on erasure of labour, see Cant this volume). This, however, does not preclude a focus that simultaneously seeks to understand how actions become meaningful to people themselves within some larger social whole. On the contrary. In so far as we are concerned with the ways in which people survive at the margins of society we need to hold together the intimate connections between the way people actually make a living and what makes a life worth living.

The relations that organize a household, obviously, consist of more than the ratio between consumers and producers. Households are also sites of deep affective attachments (Richard and Rudnyckyj 2009). The nature of such attachments will necessarily vary, depending on the kinds of and grounds for moral commitments the household is organized around, the relations of authority and the degree of control any one member can exert. The enactment of any specific labour regime is reproduced by and dependent upon the mobilisation of such particular relations. Hence, the exploitation, selfexploitation or super exploitation of a peasantry or urban slum dwellers might imply at a household level unequal relations of power or even coercion. To what extent such relations are the glue - or potential undoing - of the household will turn on the moral values and affective bonds that can be summoned not only 
within the household but also more broadly: to the people, to the place, to the land. But perhaps more importantly, the commitment of any one household member will depend on whether there are viable or desirable options. Whatever the case, affect will be at work, placing kinship and gender, as well as religious beliefs or other forms of affiliations as important dimensions in securing household viability.

Households, however, are not necessarily at one and the same time a unit of production and unit of consumption. The separation between work life and family life has been an important characteristic of modern, industrial economies, and the relation between production and reproduction a core issue for feminist studies. As Rudie (2001) points out, households are involved in both external and internal relations, where the former has to do with economic efficiency (market transactions) and the latter with moral commitments (reciprocity). There is, according to Rudie, a tension between these two domains reflecting the external and internal relational network that a household is involved in. In other words, the household must hold together these two contradictory operational domains. This is, among other things, what householding is also about. Rudie insists that this differentiation is most marked in western industrialized societies, where there is an acknowledged separation between 'a market model' and a 'love model', or what we might today label more broadly an 'affective model', necessarily paying heed to kinship relations. Whether this distinction is universal is, of course, an empirical question, which must be examined in each case. 
While ignoring the affective dimensions of labour (market relations),

Rudie nevertheless alerts us to specific and at times contradictory processes that are at work within a household. Her focus is on situations where productive and reproductive labour are separate domains, while all the while paying attention to how these domains are related. It is precisely by reading across these domains, that we can bring together the efforts and creativity that go into making a life and making a living (see also McKinnon and Cannel 2013). This will necessarily involve a double focus: on the one hand, a focus on those relations and practices that contribute toward reproducing a particular economy (through relations of labour) and on the other, those relations and practices that contribute towards creating a livelihood. These two domains are mutually constitutive, if not overlapping, incorporating at one and the same time the transformative and integrative potentials of social life.

To what extent household analysis are fruitful for anthropological approaches to labour will necessarily depend on what forms of labour are being scrutinized and how this labour is organized. It seems that those cases were the unit of production and consumption overlap, household analysis are useful. In situations were productive and reproductive labour are separate domains, while all the while paying attention to how these domains are related, household analysis alone might not yield the fine grained ethnography that illustrates these intimate links. Nevertheless, work life and family life are mutually imbricated and must be viewed in conjunction. Both the tension and the significance of the relationship between these domains can productively be explored by incorporating an affective dimension in the relational analysis of households and 
not least, by being attentive to the significance of affective labour within the family (Melhuus and Borchgrevink 1984).

\section{Conclusion}

In this paper my overall concern has been tied to the diverse ways that labour is configured under capitalism - and anthropology's shifting relationship to examinations of labour. Assuming that labour is the source of economic value, I have argued that there is something to be gained by a continued focus on economic value in so far as we are concerned with the ways capital subsumes labour and how this affects the everyday lives of labouring people across the world. From this perspective, I suggest some notion of the value of labour still has currency and one challenge is to uncover the forms that this value takes, be it as 'unpaid' labour in conditions of self-exploitation, or even super exploitation, as actors in an informal market or as outsourced self-employed entrepreneurs. All such work practices are variations of a flexible labour 'market' under uncertain conditions. They may be efficient ways of disciplining the work force and cutting labour costs, while all the while displacing the economic risks onto an already vulnerable population, creating both ambiguity and uncertainties.

As anthropologist we are interested in how people go about their lives, not just making a living, but making a life. We want to know what actions are meaningful to people and why. Work life and family life constitute two core domains that underpin people's life worlds. Both these domains coalesce around 
economic and moral values, and it is this very configuration that also permits certain forms of exploitation. Hence, labour practices and the concomitant regimes of labour must be seen in conjunction with regimes of value; political economy and moral economy must come within the frame (Narotzky and Besnier 2014). I have argued that the household can serve as a useful tool and significant entry point in order to capture these two dimensions of livelihood. Households straddle the market and non-market domains and householding embraces the many activities and relations, as well as intimacies, that make life meaningful. Importantly, also, households are processual entities, thus revealing of a particular temporal and relational dynamics. Household analysis may, then, also contribute to grasping emerging dislocations in time (such as that between labour time and personal time) and the way these are linked to local conditions of opportunity, a point Narotzky (this volume) makes in her discussion of KrohnHansen's (this volume) analysis of time work rhythms. Hence, I find household analysis particularly productive in our ethnographic enquiries where labour, labour relations and labour practices are in focus, all the while keeping in mind the affective stuff that holds these relations and practices together.

If the logic of capital tends to abstract the economic from all other relations, the anthropological perspective is to insist that economic relations are not only embedded in but also constituted by relations of kinship, gender, ethnicity, religion etc. That this also holds true also for capitalist enterprises has been amply demonstrated (Yanagisako 2002, Mollona 2009, McKinnon and Cannell 2013). The current interest in labour and labour regimes invites us to re-explore the ways labour have been understood and approached 
ethnographically and consider these in conjunction with contemporary processes of transformation and struggle for even a minimal survival. Such efforts necessarily entail a broader scope, not least the specific historical and political context. Global inequalities have not diminished but have taken on a different character. Combining detailed ethnography of the minutiae of everyday life and relational dependencies (labouring and otherwise), anthropology is well placed to grasp contemporary configurations of labour and how these are both framed by and contribute towards reproducing social and economic inequalities, not only locally, but also at a more global scale.

\section{References}

Archetti, E. P. and K. A. Stølen. 1975. Explotación familiar y accumulación de capital. Buenos Aires: Siglo XXI.

Breman, J. 2013. A Bogus Concept? New Left Review 84, 130 -138.

Calvo, C. and A. Percíncula. 2012. Ligas Agrarias en Chaco y Corrientes. Experiencias de organización campesina en contextos de transformación territorial. De Prácticas y Discursos. Cuadernos de Ciencias Sociales 1 (1):1-36. Chayanov, A.V. 1966. On the Theory of Non-Capitalist Economic Systems. In A.V. Chayanov on the Theory of Peasant Economy (eds) D. Thorner, B. Kerbaly and R.E.F. Smith . Richard D. Irwin, p $1-28$.

Cross, J. 2010. Neoliberalism as unexceptional: Economic zones and the everyday precariousness of working life in South India. Critique of Anthropology 30, 355 -372. DOI 10.1177/0308275X10372467. Downloaded April 15, 2014 from coa.sagepub.com/content/30/4/355 
Denning, M. 2010. “Wageless Life”. New Left Review 66:79-97.

Duus, S. E. 1978. Tobakk og Politikk. Institutt for offentlig adminstrasjon.

University of Bergen.

Fortes, M. 1969 [1958] Introduction. In The Developmental Cycle in Domestic Groups (ed) J. Goody, 1 - 14. Cambridge: Cambridge University Press.

Goldstein, D. M. 2003. Laughter Out of Place. Race, Class, Violence and Sexuality in a Rio Shanty Town. Berkeley: University of California Press.

Goody, J. (ed). 1969 [1958]. The Developmental Cycle in Domestic Groups.

Cambridge: Cambridge University Press.

Graeber, D. 2001. Toward an Anthropological Theory of Value: The False Coin of Our Own Dreams. New York, NY: Palgrave.

Gregory, C. 2009. Whatever happened to householding? In Market and Society:

The Great Transformation Today. (eds) C. Hann and K. Hart, 133 - 159.

Cambridge: Cambridge University Press.

Gregory, C. 2014. On religiosity and commercial life. Toward a critique of cultural economy and posthumanist value theory. Hau: Journal of Ethnographic Theory 4(3), 45-68.

Guyer, J. I. 2017. Survivals as Infrastructure: Twenty-first Century Struggles with Household and Family in Formal Computations. In Infrastructures and Social Complexity: A Companion (eds) P. Harvey, C.B. Jensen, A. Morita, 323 - 334. London: Routledge.

Han, C. 2012. Life in Debt. Times of Care and Violence in Neoliberal Chile. Berkeley: University of California Press. 
Hann, C. and K. Hart. 2009. Introduction: Learning from Polanyi 1. In Market and Society: The Great Transformation Today (eds) C. Hann and K. Hart, 1 - 16. Cambridge: Cambridge University Press.

Hann, C. and K. Hart. 2011. Economic Anthropology. History, Ethnography, Critique. Cambridge: Polity Press.

Kearney, M. 1996. Reconceptualising the Peasantry. Anthropology in Global Perspective. Boulder, Colorado: Westview Press.

Lazar, S. 2008. El Alto, Rebel City. Self and Citizenship in Andean Bolivia. Durham: Duke University Press.

Li, T. M. 2009. To Make Live or Let Die? Rural Dispossession and the Protection of Surplus Populations. Antipode 41: 66 -93. Doi. 10.1111/j.14678330.2009.00717.x

Li, T. M. 2011. Centering labor in the land grab debate. Journal of Peasant Studies 38 (2), 281-298.

Martínez-Torres, M. and P.M. Rosset .2010. La Vía Campesina: the birth and evolution of a transnational social movement. The Journal of Peasant Studies 37 (1), 149 - 175, DOI: 10.1080/0306615903498804. Downloaded 03 December $2015,0359$.

McKinnon, S. and F. Cannell. 2013. The Difference Kinship Makes. In Vital Relations and the Persistent Life of Kinship (eds) Susan McKinnon and Fenella Cannell, 3 - 38. Santa Fe: SAR Press.

McKinnon, S. and F. Cannell (eds). 2013. Vital Relations and the Persistent Life of Kinship. Santa Fe: SAR Press.

McMichael, P. 1997. Rethinking Globalization: The Agrarian Question. Review of International Political Economy 4 (4) 630 - 662. 
Melhuus, M. 1987. Peasants, Surpluses and Appropriation. A case study of tobacco growers from Corrientes, Argentina. Oslo Occasional Papers in Social Anthropology. University of Oslo.

Melhuus, M. and T. Borchgrevink. 1984. Husarbeid: Tidsbinding av kvinner. In Myk start - hard landing (ed) I. Rudie, 319-338 . Oslo: Universitetsforlaget. Meillassoux, C. 1973. The Social Organization of the Peasantry. Journal of Peasant Studies, 1 (1), 81 - 90.

Millar, K. M. 2014. The Precarious Present: Wageless Labor and Disrupted Life in Rio de Janeiro, Brazil. Cultural Anthropology 29 (1), 32 - 53. DOI:

10.14506/ca29.1.04.

Mintz, S. W. 1973. A note on the definition of peasantry. Journal of Peasant Studies 1(1), 91-106.

Mollona, M. 2009. Made in Sheffield. An Ethnography of Industrial Works and Politics. Berghahn Books: New York

Narotzky, S. and N. Besnier. 2014. Crisis, Value and Hope: Rethinking the Economy: An Introduction. Current Anthropology 55, (S9) S4 -S16.

http://www.jstor.org/stable/10.1086/676327. Accessed 08/05/2015 10:39. Rudie, I. 2001 [1969]. Husholdsorganisasjon. Tilpasningsprosess og restriktiv form. Et synspunkt på økonomisk endring. In Sosialantropologiske grunntekster (ed) T. H. Eriksen 147 - 164. Oslo: Gyldendal.

Sahlins, M. 1974. Stone Age Economics. London: Tavistock.

Shanin, T. (ed.). 1971. Peasant Societies. Hammondsworth, England: Penguin Books.

Stavenhagen, R. 1973 [1969]. Las clases sociales en las sociedades agrarias. Mexico: Siglo XXI. 
Stenning, D. J. 1969 [1958]. Household Viability among the Pastoral Fulani. In The Developmental Cycle in Domestic Groups (ed) J.Goody, 99-119. Cambridge: Cambridge University Press.

Tsing, A. 2009. Supply Chains and the Human Condition. Rethinking Marxism: Journal of Economics, Culture and Society, 21(2) 148 - 176.

Wolf, E. R. 1966. Peasants. Englewood Cliffs, N.J.: Prentice Hall.

Yanagisako, S. 1979. Family and Household: The Analysis of Domestic Groups. Annual Review of Anthropology 8, 161 - 205.

Yanagisako, S. 2002. Producing Culture and Capital. Family Firms in Italy. Princeton: Princeton University Press.

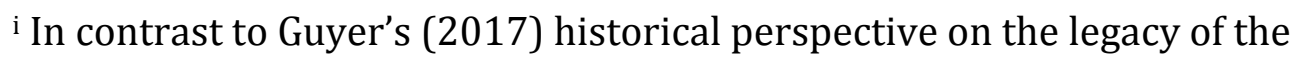
household, my take is methodological. Framing her discussion in terms of infrastructure, Guyer examines the classical elements of the household, alerting us to the way the household has been deployed over time. In this effort she makes an interesting analytical distinction between the 'house' (material good and container) and the 'hold' (as relations of dependency). ii See Kearney 1996. Although the category of the peasant may be obsolete, the 'campesino' is still thriving. One of the major contemporary rural organisations is 'La Via Campesina' (Martínez-Torres and Rosset 2010). Moreover, rural 
populations are continuously facing acute problems, dispossession and land grabbing being salient (Li 2009, 2011).

iii I travelled with Svein Erik Duus. We had each received grants from the Norwegian Research Council (then NAVF) to carry out our respective projects on tobacco.

iv The Agrarian Leagues sprung out of the Movimiento Rural de Acción Católica and were the first independent organizations of the peasants and rural poor in Argentina. For a brief historical overview of the development of Las Ligas Agrarías in Corrientes until the 1970s see Calvo and Percíncula 2012.

${ }^{v}$ My introduction to the Agrarian Leagues was through Eduardo Archetti. He was at the time completing his fieldwork, together with Kristi Anne Stølen, among the colonos in the northern part of Sta Fé. See Archetti and Stølen 1975. My fieldwork lasted 13 months, from June 1974 to July 1975.

vi Her full name: Maria Estela Martinez de Peron; but known as Isabel or Isabelita.

vii The Argentinian state is also involved, through state policies directed at the producers, such as the Fondo especial de tabaco (created in 1967) and the Provincial Tobacco Institute created in 1964. For an analysis of state policies and the development of the tobacco industry in Argentina, see Duus 1978; for a short introduction see Melhuus 1987.

viii Access to this particular estancia was facilitated by the LAC. I also did a short comparative project amongst small landowning cultivators (minifundios), in order to capture the movement between being landless producers and being small landowning tobacco cultivators. 
ix When I wrote the preface to the published version (1987) of my original thesis (from 1978), I formulated some of the main criticisms that had since been raised against Marxism, dependency theories and the like. Most importantly these turned on the question of structure versus agency (structural determinism); the lack of attention to the cultural dimension; and the absence of a gender perspective.

${ }^{x}$ At the time of my study, the Department of Goya was characterised by a concentration of land on few hands. $56.3 \%$ of the property units were less than 50 hectares comprising only $3.7 \%$ of the total area. At the other extreme, $70 \%$ of the total area belonged to estates over 1000 hectares or more, totalling $4.9 \%$ of the property units. Moreover, of a registered 7816 tobacco producing units, 5638 were landless, i.e. around 70\%; and of these 73.3\% had holdings under 9 hectares (for details see Melhuus 1987, pages 45-50). xi There were a total of 22 families/households living on his property. The landowner also had ca1000 head of cattle. Of the 22 households, fourteen were apaceros; two were peones who worked for a wage minding the cattle and doing general maintenance work; four were pobladores, who in exchange for their labour on the estancia, were given the right to cultivate some land; two were ocupantes gratuitos, occupying the land free of charge.

xii The households varied in size from a total of 4 to 15 persons. One household consisting of 15 persons had a very favourable composition: 7 females and 8 males, with nine of the members being between 14 and 60 years of age. This household was able to cultivate 9.5 has of tobacco, and had been able (as the only 
one within the estancia) to purchase a tractor on credit (Melhuus 1987: table 4.3 and 4.4, p 123 and 135).

xii To plant one hectare of tobacco $18000-25000$ plants were needed. The tobacco was harvested leaf by leaf as they matured; they were first dried under shelter of a roof, then moved out to dry in the sun. At the slightest sign of rain, the tobacco had to be moved into shelter. 